University of Nebraska - Lincoln

DigitalCommons@University of Nebraska - Lincoln

USGS Staff -- Published Research

US Geological Survey

2007

Population viability analysis of Lower Missouri River shovelnose sturgeon with initial application to the pallid sturgeon

P. G. Bajer

U.S. Geological Survey

M. L. Wildhaber

U.S. Geological Survey

Follow this and additional works at: http://digitalcommons.unl.edu/usgsstaffpub

Bajer, P. G. and Wildhaber, M. L., "Population viability analysis of Lower Missouri River shovelnose sturgeon with initial application to the pallid sturgeon" (2007). USGS Staff-- Published Research. 850.

http:// digitalcommons.unl.edu/usgsstaffpub/850

This Article is brought to you for free and open access by the US Geological Survey at DigitalCommons@University of Nebraska - Lincoln. It has been accepted for inclusion in USGS Staff -- Published Research by an authorized administrator of DigitalCommons@University of Nebraska - Lincoln. 


\title{
Population viability analysis of Lower Missouri River shovelnose sturgeon with initial application to the pallid sturgeon
}

\author{
By P. G. Bajer and M. L. Wildhaber \\ U.S. Geological Survey, Columbia Environmental Research Center, Columbia, MO, USA
}

\section{Summary}

Demographic models for the shovelnose (Scaphirhynchus platorynchus) and pallid (S. albus) sturgeons in the Lower Missouri River were developed to conduct sensitivity analyses for both populations. Potential effects of increased fishing mortality on the shovelnose sturgeon were also evaluated. Populations of shovelnose and pallid sturgeon were most sensitive to age- 0 mortality rates as well as mortality rates of juveniles and young adults. Overall, fecundity was a less sensitive parameter. However, increased fecundity effectively balanced higher mortality among sensitive age classes in both populations. Management that increases population-level fecundity and improves survival of age- 0 , juveniles, and young adults should most effectively benefit both populations. Evaluation of reproductive values indicated that populations of pallid sturgeon dominated by ages $\geq 35$ could rapidly lose their potential for growth, particularly if recruitment remains low. Under the initial parameter values portraying current conditions the population of shovelnose sturgeon was predicted to decline by $1.65 \%$ annually, causing the commercial yield to also decline. Modeling indicated that the commercial yield could increase substantially if exploitation of females in ages $\leq 12$ was highly restricted.

\section{Introduction}

Shovelnose sturgeon (Scaphirhynchus platorynchus) and pallid sturgeon (S. albus) are endemic to the Missouri and Mississippi River drainage (Keenlyne, 1997). Populations of these historically abundant fishes have declined markedly over the last 100 years due to overexploitation and anthropogenic degradation of the Mississippi and Missouri rivers (Keenlyne, 1997; Mayden and Kuhajda, 1997). In response to dramatic decline in abundance and sporadic recruitment, the pallid sturgeon was listed as endangered in 1990 (Mayden and Kuhajda, 1997). In addition to establishing federal protection, annual stocking with juvenile pallid sturgeon reared from wild broodstock has continued since the early 1990s to enhance recovery of the species (R. Holm, U.S. Fish and Wildlife Service-USFWS, Garrison Dam NFH, ND). Also, habitat restoration in the Lower Missouri River has been initiated by periodic flow modifications and specific hydro-engineering to potentially improve spawning success of adults and survival of juvenile pallid sturgeon (USFWS, 2003).

Shovelnose sturgeon are considered extirpated, threatened, or of special concern in 15 out of 24 states within their natural range (Keenlyne, 1997). Populations in remaining states are either declining or of unknown status (Keenlyne, 1997). Despite these alarming trends in population decline, the shovelnose sturgeon is still being harvested commercially or as a sport fish in nine states. In fact, commercial demand for the shovelnose sturgeon has recently increased because of the rising demand for caviar exacerbated by the recent collapse of sturgeon fisheries in Europe and Asia (Birstein, 1993).

Understanding population dynamics is essential in effective recovery of rare or declining species, and also in determining sustainable exploitation schemes of commercially exploited species. Population viability analysis (PVA), which allows for identification of the most sensitive demographic parameters, has been successfully applied to establish biologically sound protection plans (Crouse et al., 1987). To date, such analyses have not been developed for shovelnose and pallid sturgeon.

In this paper we developed deterministic age-based population dynamics models for the shovelnose and pallid sturgeon in the Lower Missouri River (from Gavins Point Dam, South Dakota to the confluence of the Missouri and Mississippi rivers in St Louis, Missouri). The population models are used to conduct a PVA for both sturgeon species in the Lower Missouri River and elucidate the combinations of most sensitive demographic processes and age classes that largely determine the status of both populations. The shovelnose sturgeon population dynamics model is also used to evaluate commercial fishing regulations that could potentially lead to more sustainable yields by recognizing sensitive population parameters and age classes. Identifying the most sensitive population parameters and calculating age-specific reproductive values should also enhance pallid sturgeon recovery efforts.

\section{Materials and methods}

We developed age-structured models for shovelnose and pallid sturgeon populations in the Lower Missouri River. Modeling of both populations was restricted to females (Donovan and Welden, 2002), under the assumption that male abundance was sufficient to fertilize eggs (Quinn and Deriso, 1999). Changes predicted for the female portion of the populations were assumed to reflect trends in whole populations; we applied equal sex ratios and the same age-specific survival rates for both females and males.

\section{Shovelnose sturgeon population model}

The model for shovelnose sturgeon included age classes from 0 (starting from eggs) to 31, the oldest fish collected in the Lower Missouri River (Wildhaber et al., 2005). Number of females in 
each age class during the current year $\left(N_{i, t} ; i\right.$ indicates age class, $t$ indicates year of simulation) was determined as

$N_{i, t}=N_{i-1, t-1} P_{i-1, i}$;

$N_{i-1, t-1}$ is the number of females in age class $i-1$ in the previous year $(t-1)$, and $P_{i-1, i}$ is the probability that a female in age $i-1$ will survive to age $i$. Egg to age-1 survival rate is notoriously variable in highly fecund broadcasting fishes and typically ranges from zero to 0.001 (Rose and Cowan, 1993; Bulak et al., 1997; Houde, 1997). We initially assumed 0.0004 survival probability from egg to age-1, a value reported for the Gulf of Mexico sturgeon (Acipenser oxyrinchus desotoi) (Pine et al., 2001).

Annual survival rate of young juveniles (ages 1 and 2) was initially set at 0.75 , an estimate determined for the Gulf sturgeon of the same age (Pine et al., 2001). Annual survival rate of ages $\geq 3$ were also initially set at 0.75 based on total mortality estimates for shovelnose sturgeon in the Lower Missouri River (Quist et al., 2002). Total annual mortality rate of age $\geq 3$ shovelnose sturgeon in the Lower Missouri River was initially set at $Z=0.25$ (Quist et al., 2002). This mortality was assumed to be comprised of fishing mortality $(F=0.18)$ and natural mortality $(M=0.07)$ after Quist et al. (2002) who reported 0.07 average natural mortality rate for the commercially unexploited population of shovelnose sturgeon in the Middle Missouri River.

A von Bertalanffy growth equation was used to predict fork length (FL) at age for the Lower Missouri River shovelnose sturgeon,

$\mathrm{FL}_{i}=L_{\infty}\left[1-\mathrm{e}^{-K\left(i-t_{0}\right)}\right]$,

where $\mathrm{FL}_{i}$ is $\mathrm{FL}$ at age $i(\mathrm{~mm}), L_{\infty}$ is asymptotic $\mathrm{FL}, t_{0}$ is a theoretical age at length zero, and $K$ is a growth coefficient that determines how rapidly FL increases to $L_{\infty}$. Parameters of the von Bertalanffy equation for the shovelnose sturgeon in the Lower Missouri River were determined by Quist et al. (2002)

$\mathrm{FL}_{i}=660 \times\left(1-\mathrm{e}^{-0.191 \times(i+0.269)}\right)$

Equation 2 was originally developed by Quist et al. (2002) for fish of less than 18 years of age. However, using data from Wildhaber et al. (2005) for 74 shovelnose sturgeon ages 10 to 31, we determined that the Quist et al. (2002) equation accurately predicted average FL for shovelnose sturgeon of up to 31 years of age (results not presented). Therefore, the Quist et al. (2002) equation was incorporated into the shovelnose sturgeon model without modification.

To develop a relationship between shovelnose sturgeon FL $(\mathrm{mm})$ and number of eggs produced by an average female $(E)$, individual data of the same 74 shovelnose sturgeon females 542 $\mathrm{mm}$ to $760 \mathrm{~mm}$ FL were used (Bryan et al., 2006). To expand the range of relationship for smaller shovelnose sturgeon females, an additional data set comprised of 30 females 428 $\mathrm{mm}$ to $615 \mathrm{~mm}$ FL was also incorporated (Zweiacker, 1967). A single exponential relationship was fit to the combined data sets $\left(r^{2}=0.69 ; \mathrm{P}<0.0001\right)$ (Fig. 1):

$E=-288463+110056 \log (\mathrm{FL})$.

Fork lengths at age $i\left(\mathrm{FL}_{i} ; \mathrm{mm}\right)$ predicted by Equation 2 were entered in Equation 3 to predict age-specific egg production $\left(E_{i}\right)$. Because only the female portion of the population was modeled, fecundity during a year $t\left(F_{t}\right)$ was defined as the total number of eggs produced by all spawning females that could result in female offspring

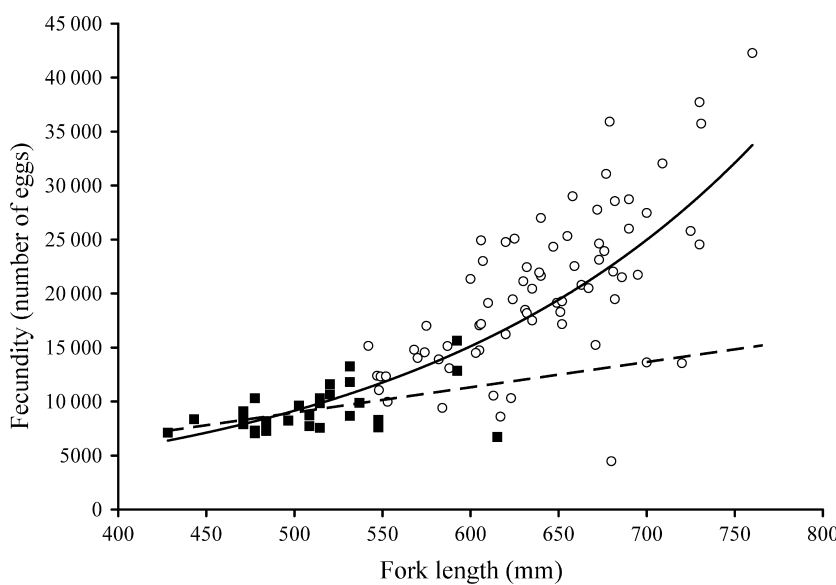

Fig. 1. Relationships (solid line) between shovelnose sturgeon (Scaphirhynchus platorynchus) fork length and fecundity fitted to combined data sets collected by Bryan et al. (2006) (open symbols) and Zweiacker (1967) (closed symbols). A separate relationship fitted solely to Zweiacker's data (closed symbols; broken line) is also presented

$F_{t}=\sum_{i=r}^{n}\left(E_{i} N_{i, t}\right) k z$

The product in the parentheses summed over ages from $r$ [age of the first reproduction of females; $r=7$ (Keenlyne, 1997)] to $n$ (age of the last reproduction; $n=31$ ) is the number of eggs produced by all mature females during year $t, k$ is the proportion of females in the population $(k=0.5$; Moss, 1978), and $z$ represents average probability that a female of reproductive age will spawn during a given year. Initially, $z$ was set at 0.4 to reflect a 2.5 -year average interval between consecutive spawns (Moss, 1978). We assumed that the population of shovelnose sturgeon in the Lower Missouri River could not exceed a carrying capacity of 3250000 individuals (combined males and females in ages 1 through 31 ). The carrying capacity was estimated by multiplying the total length of the Lower Missouri River $(1303 \mathrm{~km})$ by the average density of shovelnose sturgeon for periods before commercial exploitation began (2500 fish per kilometer; Schmulbach et al., 1974). To prevent the population from exceeding its carrying capacity, a maximum level of annual egg deposition by the population was iteratively determined $\left(F_{\max }=539000000\right)$.

Modeling of shovelnose sturgeon population dynamics was initiated by seeding age classes $1-31$ with a value of 5000 individuals each (equivalent to 240 fish $\mathrm{km}^{-1}$; approximately $10 \%$ of the carrying capacity). We determined that the initial number of individuals in the population had no effect on predicted finite rate of population change ( $\lambda$; see below).

Numbers of females in each age class were modeled over a 100 -year period. For each year the total number of females in the population $\left(N_{t}\right)$ (excluding eggs) was compared to the number during the previous year $\left(N_{t-1}\right)$ to determine finite rate of population change $\left(\lambda=N_{t} / N_{t-1}\right)$. Values of $\lambda$ were averaged over the last 80 years of simulations (by then the population reached equilibrium regardless of the initial population vector) to determine the long-term rate of population change.

\section{Pallid sturgeon population model}

The population of female pallid sturgeon in the Lower Missouri River was modeled using the same approach as described above for the shovelnose sturgeon, except for 
differences in model parameters. Because the pallid sturgeon is a longer-lived species (Keenlyne et al., 1992), the model for their population included age classes from 0 to 41 .

To estimate pallid sturgeon fecundity, the mass of ovaries was determined as a constant proportion $(11.4 \%)$ of fish mass and divided by the average egg mass $(0.01149 \mathrm{~g})$ (Keenlyne et al., 1992). Initially, females were assumed to mature at age 15 (Keenlyne and Jenkins, 1993) and spawn every 5 years [a mid-range value reported by Mayden and Kuhajda (1997)]. We initially assumed $50 \%$ females in the population.

The von Bertalanffy growth equation for the pallid sturgeon was developed from FL $(\mathrm{mm})$ at age data reported for a total of 31 pallid sturgeon by Swain et al. (1980); Keenlyne and Jenkins (1993), and the pallid sturgeon data base (S. Krentz, pers. comm.)

$\mathrm{FL}=1471.991 \times\left[1-\mathrm{e}^{-0.06539(t-0.2018)}\right]$.

A relationship between pallid sturgeon FL and weight (g) ( $W=10^{-7.64} \mathrm{FL}^{3.758}$; Keenlyne and Maxwell, 1993) was used to convert FL at age predicted by the von Bertalanffy model to weights at age that were needed to estimate fecundity.

Probabilities of survival for ages $\leq 2$ were assumed the same as for the shovelnose sturgeon. We initially assumed $93 \%$ survival of ages $\geq 3$, which is similar to the survival of the shovelnose sturgeon $>5$ years in the commercially unexploited Middle Missouri River (Quist et al., 2002).

No reliable estimates of pallid sturgeon density in the Lower Missouri River exist. The population of adults in the Missouri River between Garrison Dam and Fort Peck Dam has been estimated at 89-236 individuals (0.12-0.34 individuals $\mathrm{km}^{-1}$; Kapuscinski, 2003). Density of adult pallid sturgeon in the Lower Missouri River is believed to be lower than that in the Upper Missouri River (USFWS, 2003), possibly below 0.1 individual $\mathrm{km}^{-1}$. Therefore, we assumed that a total of 130 adult pallid sturgeon (including 65 females; 0.05 adult female $\mathrm{km}^{-1}$ ) exist in the $1300-\mathrm{km}$ reach of the Lower Missouri River. We initiated the modeling by seeding 3 females into age classes between 15 and 25 and 2 females in each of the age classes between 26 and 41 .

\section{Sensitivity analysis}

Initial probabilities of survival of each age class, estimates of egg production per female, and fraction of the population that is female were increased or decreased by $5 \%$ from their nominal values one at a time. Changes in a population's $\lambda$ that resulted from each individual parameter's increase or decrease were recorded to evaluate relative sensitivity of model parameters. Parameters $t_{0}, K$, and $L_{\text {inf }}$ used in the von Bertalanffy equations were also increased and deceased by $5 \%$ to evaluate their sensitivity. In addition to the $\pm 5 \%$ change, we also evaluated the effects of $\pm 10 \%$ and $\pm 20 \%$ change in each parameter value on $\lambda$. However, the results will not be presented here because they showed that the relative parameter sensitivity was not affected by the magnitude of induced change in a parameter's nominal value (change in $\lambda$ was a linear function of parameter change).

Because intervals between consecutive spawns can vary from 2-4 years for the female shovelnose sturgeon (Keenlyne, 1997) and from 3 to 10 years for the female pallid sturgeon (Mayden and Kuhajda, 1997), we evaluated the effect of the time interval between spawns on $\lambda$. To do so, we generated separate modeling results for each possible interval between consecutive spawns (in annual increments) by adjusting the value of annual probability of spawning $(z)$ that ranged from 0.1 (spawning every 10 years) to 0.5 (spawning every 2 years).

Similarly, the effect of the age of first female reproduction ( $r$; Equation 4) on each population's $\lambda$ was evaluated by allowing the value of $r$ to decrease to 6 or increase to 8 years from the nominal value of 7 years for shovelnose sturgeon females (Keenlyne, 1997) and range from 9 to 20 years for the pallid sturgeon females (Mayden and Kuhajda, 1997).

\section{Pallid sturgeon reproductive values}

Age-specific reproductive potentials were considered useful in relation to the pallid sturgeon propagation effort because they can indicate potential benefits that would result from stocking with equal numbers of different age classes of pallid sturgeon. Reproductive values of each age class of pallid sturgeon were calculated using the inoculation method (Donovan and Welden, 2002). The population model for pallid sturgeon (using initial parameter values) was inoculated with 1000 individuals of a given age class while setting numbers in other age classes to zero. The model was run over the 100 -year period and the total number of individuals in the population at the end of the model run was recorded. This procedure was repeated separately for each age class.

\section{Commercial fishing effect on shovelnose sturgeon}

Commercial harvest of shovelnose sturgeon in the Mississippi and Missouri rivers has recently increased at a rapid rate (USFWS, 2003) and stimulated evaluations of sustainable fishing rates (Quist et al., 2002). We evaluated combined effect of fishing exploitation rate $(F$; modeled as a percentage of each age class harvested annually) and age of first harvest $\left(t_{\mathrm{c}}\right)$ on a long term annual yield (average over the 100-year modeling period). Three levels of fishing exploitation were evaluated: $F=15 \%$ (similar to the current exploitation rate), $F=30 \%$, and $F=45 \%$. In each case, the number of fish in each exploited age class (age $\geq t_{\mathrm{c}}$ ) was reduced immediately before spawning by the specified percentage $(15 \%, 30 \%$ or $45 \%)$. Because sturgeon as small as $406 \mathrm{~mm}$ FL may be harvested (Quist et al., 2002), the youngest age of first harvest was initially set at $t_{\mathrm{c}}$ $=4$ years. The upper evaluated $t_{\mathrm{c}}$ was 20 years. In addition to imposed annual mortality due to commercial exploitation rates, a $7 \%$ natural mortality rate was applied to all age classes $\geq 3$ (Quist et al., 2002), as explained before. All other population parameters were maintained at their initial values.

\section{Results}

\section{Shovelnose sturgeon}

Under the initial parameter values, the population of shovelnose sturgeon in the Lower Missouri River was predicted to be declining at $1.65 \%$ annually $(\lambda=0.9835)$. At this rate of decline, the population would fall to $\sim 90000$ individuals (69 fish $\mathrm{km}^{-1}$ ) over the 100 -year modeling period.

Finite rate of population growth was most sensitive to annual survival rates (Fig. 2a). For example, improving survival of all age classes by $5 \%$ improved the annual rate of population growth by $4.96 \%$. This shows that a $5 \%$ improvement in the overall survival would change the population 

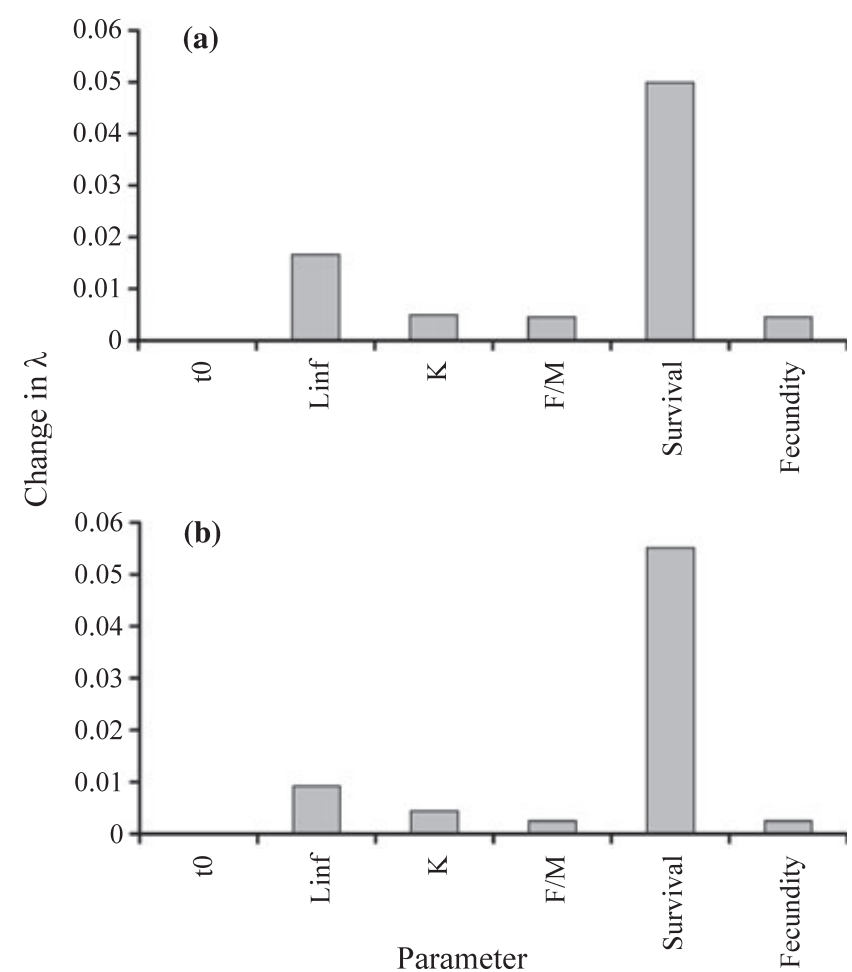

Fig. 2. Sensitivity of parameters included in population models developed for (a) shovelnose (Scaphirhynchus platorynchus) and (b) pallid sturgeon ( $S$. albus) in Lower Missouri River; $t_{0}, L_{\text {inf }}$ and $K$ are parameters included in von Bertalanffy growth models for both populations; $\mathrm{F} / \mathrm{M}$ defines proportion of females in populations. Each parameter's value was increased and decreased by $5 \%$; resulting changes in finite rate of population growth $(\lambda)$ were recorded. For clarity, only results of $5 \%$ increase in parameter values presented. A $5 \%$ decrease in parameter values caused identical but negative change in $\lambda$

status from a $1.65 \%$ decline predicted under the initial parameter values to a $3.31 \%$ annual increase.

Finite rate of population growth was most sensitive to survival of early life stages (egg to age 1) and survival of juveniles (ages 1 through 6) (Fig. 3). Increasing survival of each of these age classes by $5 \%$ improved population growth by $0.45 \%$ annually. A $5 \%$ increase in survival of all of these age groups increased population growth rate by $3 \%$, which was sufficient to reverse the projected declining trend and cause the population to increase by $1.35 \%$ annually. Rate of population growth was also highly sensitive to survival rates of young adults, particularly ages 7-10 (Fig. 3). Survival of females in ages 11-15 had a moderate effect on population growth, whereas survival of older females had only a marginal effect on the growth rate of the population (Fig. 3).

Rate of population growth was 10 times less sensitive to changes in fecundity than it was to changes in survival rates (Fig. 2a). A 5\% increase in fecundity caused the finite rate of population growth to increase by $0.45 \%$. Predicted rate of population growth was also sensitive to the $L_{\text {inf }}$ parameter included in the von Bertalanffy growth model (Fig. 2a). A 5\% increase in the $L_{\text {inf }}$ value increased the annual rate of population growth by $1.7 \%$ (Fig. $2 \mathrm{a}$ ).

Reducing intervals between consecutive spawns from 2.5 to 2 years improved the population growth rate by $2 \%$. Increasing intervals between consecutive spawns to 3 and 4 years caused the population growth rate to decline by $1.6 \%$ and $4 \%$, respectively (Fig. 4). At a 3-year interval between consecutive spawns, the population was predicted to decline by $3.8 \%$ each

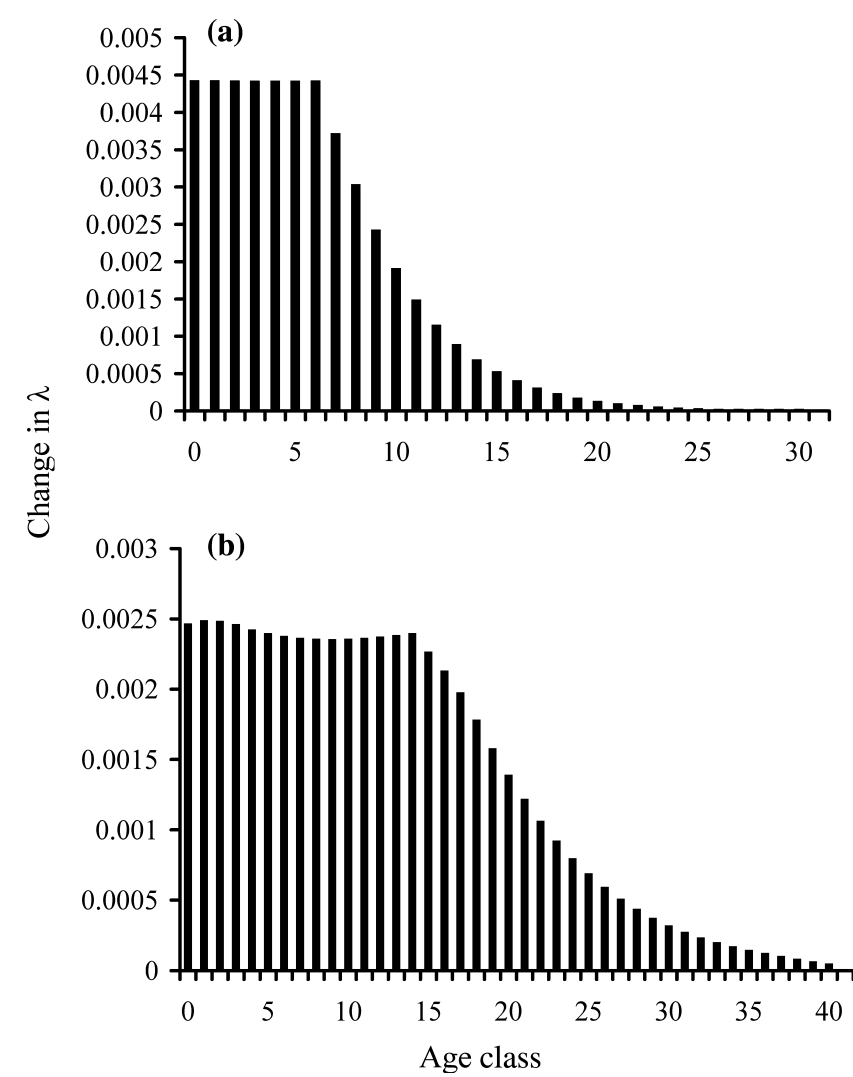

Fig. 3. Changes in finite rate of population growth rate $(\lambda)$ of (a) shovelnose (Scaphirhynchus platorynchus) and (b) pallid sturgeon (S. albus) that resulted from increasing survival probability of each age class by $5 \%$

year and fall to 8,900 individuals by the end of the 100 -year modeling period. Increasing intervals between consecutive spawn to 4 years caused the population to decline by $7 \%$ annually $(\lambda=0.93)$ and reach $<1000$ individuals within 100 years.

\section{Commercial fishing}

At the low fishing mortality rate $(F=15 \%)$ and the natural mortality rate of $7 \%$ the average annual yield increased rapidly as $t_{\mathrm{c}}$ increased from 6 to 8 years $(544 \mathrm{~mm})$ and gradually declined at higher $t_{\mathrm{c}} \mathrm{s}$ (Fig. 5). This pattern in yield indicated that a minimum FL limit of $544 \mathrm{~mm}$ would produce the highest yields at $F=15 \%$ under conditions defined by the model parameter values used.

At the higher fishing mortality rates $(F=30 \%$ and $45 \%)$ the annual yields increased rapidly at $t_{\mathrm{c}}>9$ and 10 , respectively, peaked at $t_{\mathrm{c}}=11$ and 12 , respectively, and gradually declined at higher $t_{\mathrm{c}}$. However, yields declined almost to zero if the $t_{\mathrm{c}}$ decreased below 9 and 10 at $F=30 \%$ and $F=45 \%$, respectively (Fig. 5). In both cases, the sharp decline in yield observed at lower $t_{\mathrm{c}}$ values was caused by overharvesting older juveniles and young adults, which caused the population to decline rapidly over time. The predicted pattern in yield indicates that harvesting individuals $<584 \mathrm{~mm}$ FL (age 10) at rates exceeding 15\% annually can cause rapid decline of the population. It also suggests that high annual yield could be achieved despite a high fishing mortality rate $(F$ $=45 \%$ ) if a minimum FL limit of 598-610 mm (ages 11 and 12 , respectively) was established. The predicted yields are 
Fig. 4. Effect of increasing or decreasing average spawning interval and initial maturation age on finite rate of population growth rate $(\lambda)$ of shovelnose sturgeon (Scaphirhynchus platorynchus) (upper panels) and pallid sturgeon ( $S$. albus) (lower panels) in Lower Missouri River
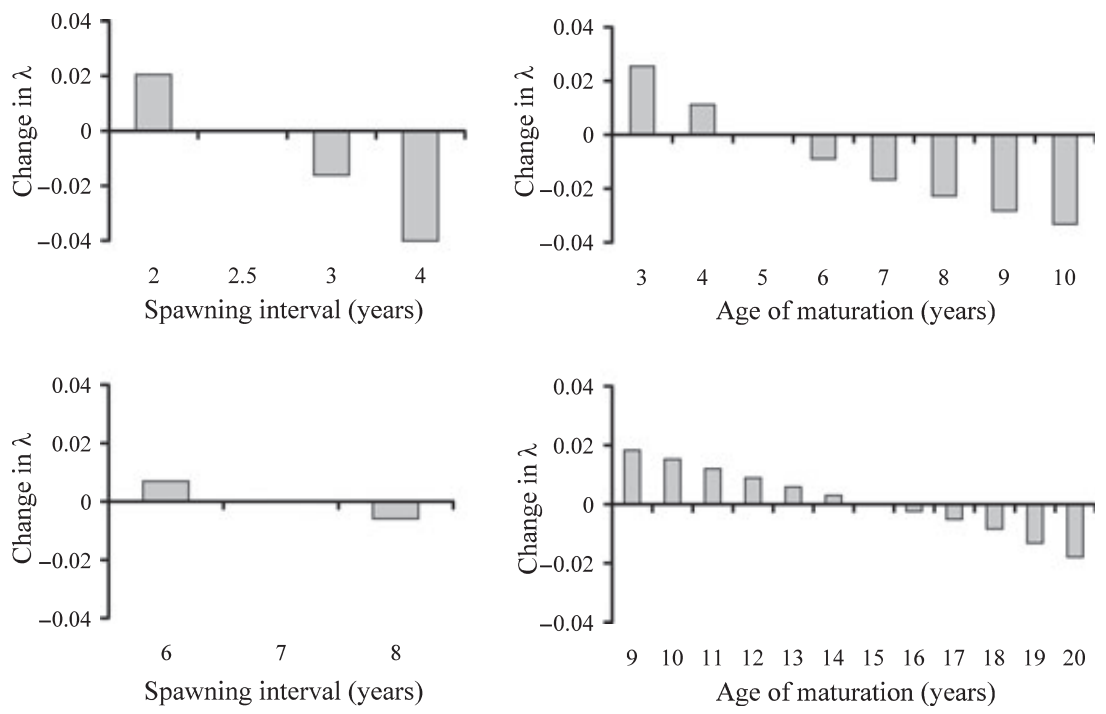

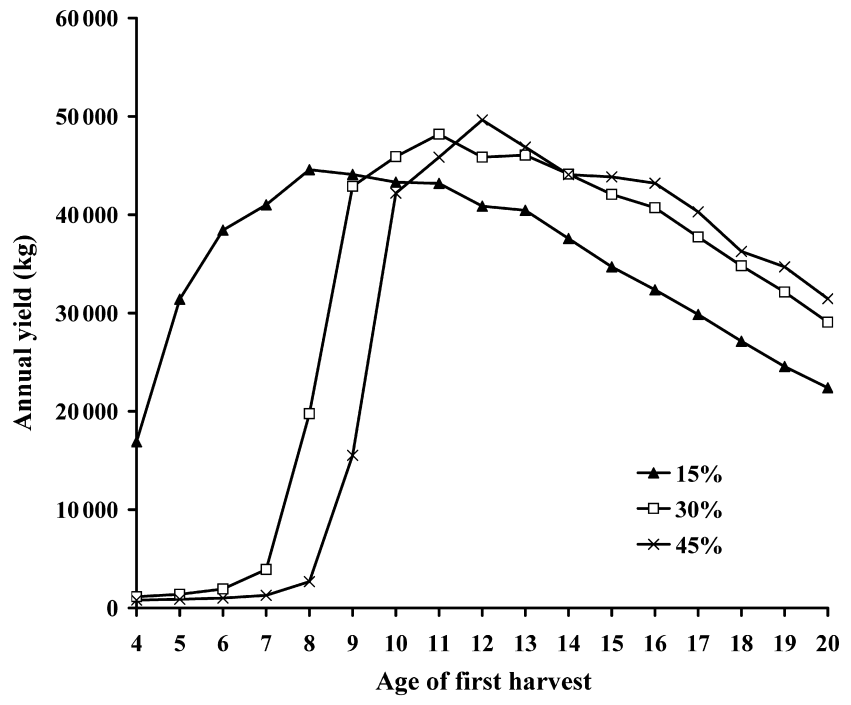

Fig. 5. Effects of commercial fishing exploitation rate $(15 \%, 30 \%$, and $45 \%)$ and age of first harvest $\left(t_{\mathrm{c}}\right)$ on annual yield of shovelnose sturgeon (Scaphirhynchus platorynchus) population in Lower Missouri River. Example, at $t_{\mathrm{c}}=6$ and exploitation rate $=30 \%, 30 \%$ of individuals in all age classes $\geq 6$ harvested annually. Harvest occurred immediately before spawning

applicable under the adopted parameter values in the shovelnose sturgeon population model.

\section{Pallid sturgeon}

The population of pallid sturgeon appeared to be most sensitive to survival rates. Increasing survival of all age groups by $5 \%$ caused population growth rate to increase by $5.5 \%$. Population growth rate was most sensitive to survival of early life stages (i.e. juveniles ages 1 to 15 and young adults ages 15 to 20). Survival of adults in ages 20-25 had lower effect on population growth rate whereas survival of older adults had only a marginal effect (Fig. 2b).

The population growth rate was much less sensitive to changes in fish fecundity. For example, a $5 \%$ increase in fecundity due to increased egg production per each female, reduced maturation age, or reduced spawning interval improved population growth rate by only $0.25 \%$. Rate of

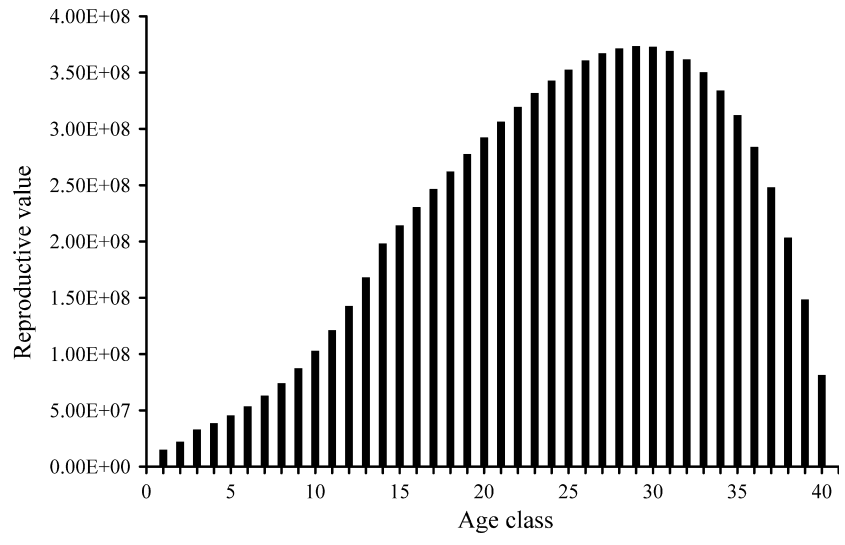

Fig. 6. Age specific reproductive values of pallid sturgeon (Scaphirhynchus albus) in Lower Missouri River

population growth was relatively insensitive to changes in male to female ratio. Among the parameters in the von Bertalanffy growth equation, the $L_{\text {inf }}$ appeared to be of high sensitivity whereas $t_{0}$ and $K$ were relatively insensitive.

Age 25-33 pallid sturgeon females had the highest reproductive values (Fig. 6), showing that populations where these age classes are abundant should have high reproductive potential. Reproductive values decreased rapidly as fish age increased $>35$ years, which indicates that populations dominated by senescent individuals ( $>35$ years) will rapidly lose their reproductive abilities if recruitment of younger age classes remains poor.

\section{Discussion}

Results of sensitivity analysis were quite similar for both shovelnose and pallid sturgeon populations, indicating that similar demographic processes are key in determining status of both populations. Growth rates of both populations were most sensitive to survival of early life stages, survival of juveniles, and survival of young adult females. High sensitivity of egg to age-1 survival rates has been shown for other sturgeon species (Pine et al., 2001). We predict that relatively slight improvements in survival rates of larvae, juvenile, and young adults have a potential to substantially increase population growth 
rate. Particularly beneficial should be management practices that would simultaneously increase survival of several age classes of juveniles or young adults by, for example, creating more habitats that improve foraging abilities and/or provide shelter from predators and harsh abiotic conditions. In such a case, the overall increase in $\lambda$ would be proportional to the number of age classes that benefited from the habitat improvement. A protection strategy that allows for simultaneous improvement of survival among several age classes of juveniles (including larvae) and young adults would also be most cost effective.

Reduced survival rates of sturgeon larvae, juveniles, and young adults due to, for example, scarcity of suitable habitats, could result in rapid population decline. The decline would increase if survival of several age classes is negatively affected. It should be noted that if improving survival of some of the sensitive ages is not possible (or practical), a strong effort should be made to substantially increase survival of other sensitive age classes as a compensatory measure.

The population growth rate was less sensitive to changes in fecundity than it was to changes in survival rates. However, this effect was partially a modeling artifact, for example, increased fecundity directly increased the number of age 0 individuals only, whereas increased overall survival affected all age classes. Still, a $5 \%$ change in fecundity had the same effect on population growth rate as a $5 \%$ change in age 0 to 1 survival rates, which was a highly sensitive parameter. Increase in fecundity has a potential to substantially improve population growth rate, and could offset increases in mortality of sensitive age classes. Efforts to increase egg deposition, for example, by creating more optimum spawning condition should be of particular importance if means of increasing survival of juveniles are limited.

Substantial decreases in fecundity due to, for example, poor spawning habitat, decreased frequency of spawning, or targeting gravid females by commercial fishermen, can substantially reduce population growth rate, or accelerate the rate of decline. In particular, harvesting young females (ages 7-12) should be limited or eliminated, because it greatly increases the risk of further population decline.

\section{Pallid sturgeon propagation}

Since 1994, over 73000 age-1 pallid sturgeon have been stocked to the Lower Missouri River (S. Krentz, USFWS, North Dakota). Observed increasing recapture rates of stocked pallid sturgeon in the Lower Missouri River indicate that stocking has a potential for enhancing recovery of the pallid sturgeon population. Stocking effectiveness could potentially be improved if older, for example, age- 2 fish were used instead of the age- 1 fish. Reproductive value of age- 1 pallid sturgeon was $66 \%$ of that determined for age- 2 individuals, indicating that stocking with the same number of age- 2 fish could result in $50 \%$ more fish added to the population as compared to stocking with an equal number of age- 1 pallid sturgeon. Therefore, if the survival rates of age-1 pallid sturgeon in the hatchery would be substantially higher than $66 \%$, holding the age- 1 fish for an additional year at the hatchery could be justified. However, our model does not include potential domestication effects that could arise due to extended holding at the hatchery.

\section{Need for more accurate parameters}

Even small changes in egg deposition and, following, larval and juvenile survival had a strong effect on shovelnose and pallid sturgeon populations. However, despite recent efforts (Bratten and Fuller, 2002; Hrabik, 2002), these parameters remain poorly evaluated. To increase our ability to predict future trends in shovelnose and pallid sturgeon populations in the Lower Missouri River, more accurate estimates of egg deposition as well as larval and juvenile survival are needed. Despite uncertainties in specific parameter values, we believe that our model generated realistic and biologically relevant predictions. For example, the predicted slow rate of decline of the shovelnose sturgeon population under the initial parameter values is in agreement with recent evaluations of the shovelnose sturgeon status in the Lower Missouri River and across its geographic distribution (Keenlyne, 1997; Herzog, 2002).

Parameters $L_{\text {inf }}$ and $K$ in the von Bertalanffy growth models appeared to be of relatively high sensitivity. These parameters are relatively well known for shovelnose sturgeon in the Lower Missouri River (Quist et al., 2002; Wildhaber et al., 2005). However, they are rather unknown for pallid sturgeon in the Lower Missouri River. We propose that more research should be directed to determine a robust length at age relationship for pallid sturgeon in the Lower Missouri River.

Predicting future trends in populations of endangered (rare) species is challenging because of relatively poorly understood complex processes that can occur at low densities of individuals in the population. For example, slower than expected recovery rates of overexploited fish stocks have been attributed to the presence of depensatory mechanisms that reduce reproductive success at low individual densities (Myers et al., 1995). In fishes that form spawning aggregations (such as pallid sturgeon), egg fertilization rates can decline by $40 \%$ if the number of males per female declines below some optimum level (Rowe et al., 2004). Increased hybridization rates with congeneric species can also result from inabilities to form sufficient spawning aggregations or from competition for suitable spawning habitat with other species (Carlson et al., 1985; Grady et al., 2001). Both depensation and hybridization are likely to play an important role in reducing recovery rates of the pallid sturgeon, despite established protection. If so, our results should be interpreted as a conservative estimate of the population decline at low individual densities, for example, the true rate of decline would be faster than the one predicted here due to the depensation or hybridization effects. Further research is needed to better evaluate magnitudes of depensation or rates of hybridization so that these effects could be incorporated into population dynamics models developed to more accurately evaluate future trends of the pallid and shovelnose sturgeon in the Lower Missouri River.

Many parameters of the population dynamics model are temporarily variable. For example, survival rates during the first year of life have been known to vary dramatically, leading to inconsistent and hard-to-predict recruitment. Instead of allowing the annual egg to age-1 survival rates to vary on an annual basis (either randomly or following a certain probability distribution), our model uses a fixed value that would result from averaging the highly variable annual egg to age-1 survival rates over longer intervals. We have determined that over the 100-year modeling interval, the estimates of $\lambda$ were very similar when the value of egg-to-age-1 survival was held constant or when it was allowed to oscillate around a certain mean value (e.g. 0.0004). Fixed values of model parameters were used because the main goal of the paper was to evaluate relative sensitivities of model parameters and for that purpose using average values for model parameters was justified (e.g. Crouse et al., 1987). In addition, we are unaware of any data 
that could be used to describe the nature (e.g. statistical distribution) of annual variability of the model parameters.

\section{Commercial fishing effects on shovelnose sturgeon}

Shovelnose sturgeon is among the last of the commercially harvested sturgeon species in North America (Keenlyne, 1997). The fishing pressure on shovelnose sturgeon has increased rapidly during the last decade (USFWS, 2003; Williamson, 2003) due to the growing market demand for caviar (sturgeon roe) caused partially by the collapse of sturgeon fisheries worldwide. For example, the commercial shovelnose sturgeon catch in Missouri increased from $5482 \mathrm{~kg}$ in 1999 to $29307 \mathrm{~kg}$ in 2001 in the Mississippi River and from $3372 \mathrm{~kg}$ in 1999 to $5566 \mathrm{~kg}$ in 2001 in the Missouri River (USFWS, 2003). The observed increase in commercial fishing, however, caused some concerns related to potential overfishing of shovelnose sturgeon stocks. Substantial declines in catch rates per unit of effort have already been documented in the Lower Missouri River (Herzog, 2002). We predict that, under the initial parameter values including the estimated current rates of natural and fishing mortality, the population of shovelnose sturgeon in the Lower Missouri River would be declining by $\sim 3 \%$ annually. At that rate of decline, the population would reach 160000 individuals (123 fish $\mathrm{km}^{-1}$ ) within the next 50 years, $5 \%$ of the historical densities (Schmulbach et al., 1974). Obviously, annual yield would decline as well. Potential increases in fishing activity to compensate for the declining catch rates would only exacerbate the rate of population decline, especially if young adult females $(<12)$ are targeted.

Our simulations indicate that annual commercial yield could be substantially improved if fishing efforts are adapted to better reflect key demographic processes that allow the shovelnose sturgeon population to increase and remain at a high level. For example, we predict that annual yields could increase substantially (up to $48000 \mathrm{~kg}$ ), despite maintaining high exploitation rates (e.g. $40 \%$ annually), if harvesting of age classes $<12$ years is restricted or eliminated. This could be achieved by establishing a minimum FL limit of approximately $610 \mathrm{~mm}$. On the other hand, harvesting young adult females and older juveniles should be limited because it can easily lead to rapid population decline if in excess of $15 \%$ annually as predicted by the model. Restricting harvest to individuals $\geq 12$ years $(>610 \mathrm{~mm} \mathrm{FL}$ ) should result in a substantial population increase, allowing for higher commercial yields. Also, targeting individuals 12 years or older should optimize roe harvest because the number of eggs produced by a female reaches a near-maximum level at age 12.

The predictions of commercial yields and abundance of the shovelnose sturgeon population presented in this paper reflect the specific values of model parameters derived from the best data available to date. We recognize the need to further assess the accuracy of model parameters used in this study as well as to evaluate major model assumptions. Efforts aiming to develop an even more accurate shovelnose sturgeon population dynamics model should be expedited by focusing on the most sensitive parameters indicated by the sensitivity analysis.

The minimum FL limit proposed in this study $(610 \mathrm{~mm})$ is substantially higher than those previously evaluated. Quist et al. (2002) evaluated effects of 406-mm and 508-mm FL limits on harvest rates of the shovelnose sturgeon population in the Missouri River. Establishing a 406-mm minimum FL limit would allow for harvesting fish ages 5 and older whereas the 508-mm FL limit would allow for harvest of fish in age classes $\geq 7$. Our analysis indicated that even a slight increase in mortality of fish in ages as low as 5 could lead to rapid population decline. Therefore we caution against harvesting older juveniles and young adults. Also, harvesting fish in ages 5-11 would be suboptimal if roe harvest is to be optimized because egg production by females in these age classes is substantially below the maximum level observed for females in ages $\geq 12$ (egg production is zero for ages $<7$ ).

Contrary to our evaluations, Quist et al. (2002) did not see a substantial difference in predicted annual yield at the $508 \mathrm{~mm}$ minimum FL limit in the Lower Missouri River, despite increasing exploitation rate from $10 \%$ to $90 \%$ (natural mortality rate was held constant at $5 \%$ annually). We find their results surprising, considering that the estimated maturation size of the shovelnose sturgeon female is $517 \mathrm{~mm}$ FL, meaning that all reproductive females would be vulnerable to harvest (majority would be harvested at the $90 \%$ exploitation rate) if the $508 \mathrm{~mm}$ minimum FL limit is applied. We predicted that moderate yields could be sustained if females in ages as young as 5 are harvested at low rates ( $15 \%$ annually). However, increasing exploitation rates of ages $\geq 5$ above $15 \%$ was predicted to cause rapid population decline and drastic reduction in commercial yields.

Yields predicted by Quist et al. (2002) under low exploitation rates (e.g. 10\%) and low natural mortality rates (e.g. 5\%) were 8 -fold lower than those predicted in this study under similar conditions. Some of the discrepancies between the two studies could result from differences in the fecundity equations used. The equation developed by Zweiacker (1967) and used by Quist et al. (2002) was based on data collected for relatively small shovelnose surgeon females (428-615 mm FL) and appeared to be inaccurate if extrapolated to predict fecundities of larger females (Fig. 1). The fecundity equation used in this study is likely more accurate because it covered the full range of shovelnose sturgeon lengths in the Lower Missouri River (up to $760 \mathrm{~mm}$ FL).

\section{Acknowledgements}

This research was funded by the U.S. Geological Survey (USGS) in support of the USFWS recovery efforts for the pallid sturgeon. Thanks to Diana Papoulias and Aaron DeLonay (USGS Columbia Environmental Research Center) and two anonymous reviewers for their insightful comments which improved the quality of this manuscript.

\section{References}

Birstein, V. J., 1993: Sturgeons and paddlefishes: threatened fishes in need of conservation. Conserv. Biol. 7, 773-787.

Braaten, P. J.; Fuller, D. B., 2002: Fort Peck flow modification biological data collection plan. Summary of 2002 activities. Report prepared for the U.S. Army Corps of Engineers, Montana Department of Fish, Wildlife and Parks, Fort Peck, MT.

Bryan, J. L.; Wildhaber, M. L.; Papoulias, D. M.; DeLonay, A. J.; Tillitt, D. E.; Annis, M. L., 2007: Estimation of gonad volume, fecundity, and reproductive stage of shovelnose sturgeon using sonography and endoscopy with application to the endangered pallid sturgeon. J. Appl. Ichthyol. 23, 411-419.

Bulak, J. S.; Crane, J. S.; Secor, D. H.; Dean, J. M., 1997: Recruitment dynamics of striped bass in the Santee-Cooper System, South Carolina. Trans. Am. Fish. Soc. 126, 133-143.

Carlson D. M.; Pflieger, W. L.; Trial, L.; Haverland, P. S., 1985: Distribution, biology and hybridization of Scaphirhynchus albus 
and $S$. platorynchus in the Missouri and Mississippi Rivers. Environ. Biol. Fishes 14, 51-59.

Crouse, D. T.; Crowder, L. B.; Caswell, H., 1987: A stage-based population model for loggerhead sea turtles and implications for conservation. Ecology 68, 1412-1423.

Donovan, T. M.; Welden, C. W., 2002: Spreadsheet exercises in conservative biology and landscape ecology. Sinauer Associates, Inc., Sutherland, MA.

Grady, J. M.; Milligan, J.; Gemming, C.; Herzog, D.; Mestl, G.; Sheehan, R. J., 2001: Pallid and shovelnose sturgeons in the Lower Missouri and Middle Mississippi Rivers. Final Report for MICRA. US Fish and Wildlife Service, Columbia, MO.

Herzog, D., 2002: Open river filed station report for January 2002 Missouri Department of Conservation, Fisheries Research, Assessment and Monitoring Section, Open River Field Station, Cape Girardeau, MO.

Houde, E. D., 1997: Patterns and consequences of selective processes in teleost early life histories. In: Early life history and recruitment in fish populations. R. C. Chambers and E. A. Trippel (Eds). Chapman and Hall, London, pp. 173-196.

Hrabik, R. A., 2002: Missouri Department of Conservation Fisheries Research, Assessment and Monitoring Section. In: Pallid sturgeon recovery update, Issue no. 12. R. Wilson (Ed.). USFWS, Bismarck, ND. p. 4.

Kapuscinski, K., 2003: Population abundance estimation of wild pallid sturgeon in recovery-priority management area \#2 of the Missouri and Yellowstone Rivers, 1991-2003, draft report. Montana Fish Wildlife and Parks, Fort Peck, MT.

Keenlyne, K. D., 1997: Life history and status of the shovelnose sturgeon, Scaphirhynchus platorynchys. Environ. Biol. Fishes 48, 291-298.

Keenlyne, K. D.; Grossman, E. M.; Jenkins, L. G., 1992: Fecundity of pallid sturgeon. Trans. Am. Fish. Soc. 121, 139-140.

Keenlyne, K. D.; Jenkins, L. D., 1993: Age at sexual maturity of the pallid sturgeon. Trans. Am. Fish. Soc. 122, 393-396.

Keenlyne, K. D.; Maxwell, S. J., 1993: Length conversions and lengthweight relations for pallid sturgeon. N. Am. J. Fish. Manage. 13, 395-397.

Mayden, R. L.; Kuhajda, B. R., 1997: Threatened fishes of the world Scaphirhynchus albus (Forbes and Richardson, 1905). Environ. Biol. Fishes 48, 420-421.

Moss, R. E., 1978: Movement and reproduction of the shovelnose sturgeon, Scaphirhynchus platorynchus (Rafinesque), in the Missouri River, South Dakota. Ph.D. dissertation. University of South Dakota, Vermillion, SD.

Myers, R. A.; Barrowman, N. J.; Hutchings, J. A.; Rosenberg, A. A., 1995: Population dynamics of exploited fish stocks at low population levels. Science. 269, 1106-1108.

Pine, W. E.; Allen, M. S.; Dreitz, V. J., 2001: Population viability of the Gulf of Mexico sturgeon: Inference from capture-recapture and age-structured models. Trans. Am. Fish. Soc. 130, 1164-1174.
Quinn, T. J.; Deriso, R. B., 1999: Quantitative fish dynamics. Oxford University Press, New York, NY.

Quist, M. C.; Guy, C. S.; Pegg, M. A.; Braaten, P. J.; Pierce, C. L.; Travnichek, V. H., 2002: Potential influence of harvest on shovelnose sturgeon populations in the Missouri River system. N. Am. J. Fish. Manage. 22, 537-549.

Rose, K. A.; Cowan J. A. Jr., 1993: Individual-based model of young of the year striped bass population dynamics. I. Model description and baseline simulations. Trans. Am. Fish. Soc. 122, 415-438.

Rowe, S.; Hutchings, J. A.; Bekkevold, D.; Rakitin, A., 2004: Depensation, probability of fertilization, and the mating system of Atlantic cod (Gadus morhua L.). ICES J. Marine Sci. 61, 1144 1150 .

Schmulbach, J. C.; Gould, G.; Groen, C. L., 1974: Relative abundance and distribution of fishes in the Missouri River, Gavins Point dam to Rulo, Nebraska. S D Acad. Sci. 54, 194-222.

Swain, D. P.; Derksen, A. J.; Koch, J. S., 1980: A literature review of life histories of some species of fish - rainbow smelt Osmerus mordax, gizzard shad Dorosoma cepedianum, paddlefish Polyodon spathula, shovelnose sturgeon Scaphirhynchus platorynchus, pallid sturgeon Scaphirhynchus albus and shortnose gar Lepisosteus platostomus - that may be introduced into the Hudson Bay watershed from the Missouri River watershed as a result of the Garrison Diversion. Fisheries Biological Services, Manitoba Department of Natural Resources, MB, Canada, MS Report No. 80-37.

USFWS, 2003: Amendment to the 2000 biological opinion on the operation of the Missouri River Main Stem Reservoir System, operation and maintenance of the Missouri River Bank Stabilization and Navigation Project, and operation of the Kansas River Reservoir System. US Fish and Wildlife Service, Bismarck, ND.

Wildhaber, M. L.; Papoulias, D. M.; DeLonay, A. J.; Tillitt, D. E.; Bryan, J. L.; Annis, M. L.; Allert, J. A., 2005: Gender identification of shovelnose sturgeon using ultrasonic and endoscopic imagery and the application of the method to the pallid sturgeon. J. Fish. Biol. 67, 114-132.

Williamson, D. F., 2003: Caviar and conservation: status, management and trade of North American sturgeon and paddlefish. TRAFFIC North America, Washington, DC. World Wildlife Fund.

Zweiacker, P., 1967: Aspects of the life history of the shovelnose sturgeon, Scaphirhynchus platorynchus (Rafinesque) in the Missouri River, M.A. Thesis. University of South Dakota, Vermillion, SD.

Author's address: Mark L. Wildhaber, U.S. Geological Survey, Columbia Environmental Research Center, 4200 New Haven Road, Columbia, MO 65201, USA. E-mail: mwildhaber@usgs.gov 